\title{
I CALL
}

TO

REMEMBRANCE 

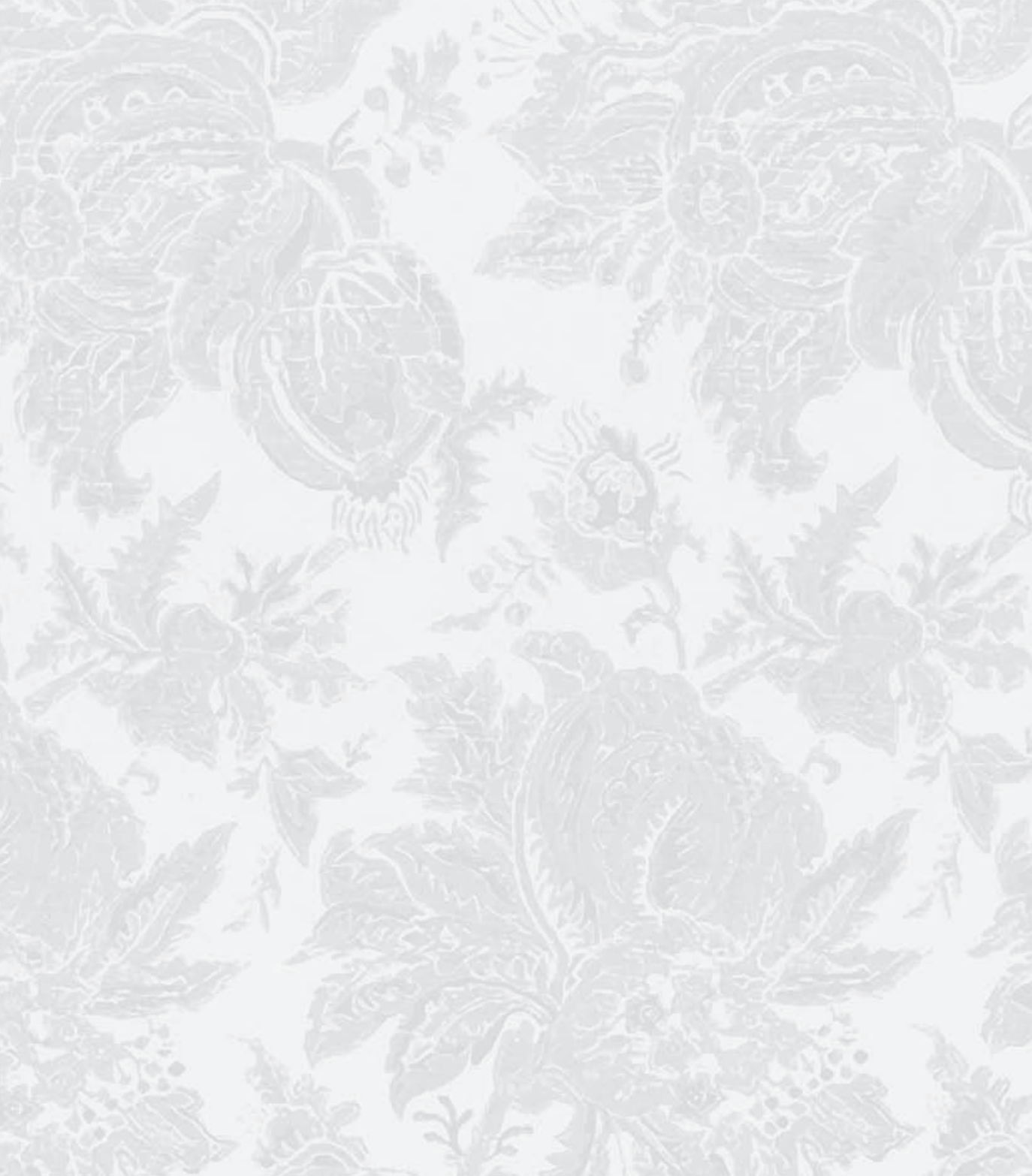

8 


\title{
I CALL
}

\author{
TO
}

REMEMBRANCE

TOYO SUYEMOTO'S

YEARS OF

INTERNMENT

Edited by Susan B. Richardson

Rutgers University Press

NEW BRUNSWICK, NEW JERSEY, AND LONDON 
Library of Congress Cataloging-in-Publication Data

Suyemoto, Toyo, 19I6-2003.

I call to remembrance: Toyo Suyemoto's years of internment / edited by Susan B. Richardson. p. $\mathrm{cm}$.

Includes bibliographical references.

ISBN-I3: 978-0-8I35-407I-9 (bbk. : alk. paper)

ISBN-I3: 978-8135-4072-6 (pbk. : alk. paper)

I. Suyemoto, Toyo, 1916-2003. 2. Central Utah Relocation Center. 3. Japanese AmericansEvacuation and relocation, 1942-1945. 4. World War, 1939-1945-Concentration camps-Utah —Topaz. 5. World War, 1939-1945-Personal narratives, American. 6. Japanese AmericansBiography. I. Richardson, Susan B., I936- II. Title.

D769.8.A6S89 2007

$940.53^{\prime} 1779245-d c 22$

[B]

2006032246

A British Cataloging-in-Publication record for this book is available from the British Library

Copyright () 2007 by Rutgers, The State University of New Jersey

All rights reserved

No part of this book may be reproduced or utilized in any form or by any means, electronic or mechanical, or by any information storage and retrieval system, without written permission from the publisher. Please contact Rutgers University Press, Ioo Joyce Kilmer Avenue, Piscataway, NJ 08854-8099. The only exception to this prohibition is "fair use" as defined by U.S. copyright law.

TEXT DESIGN AND COMPOSITION BY JENNY DOSSIN

Manufactured in the United States of America 
For Toyo

3 


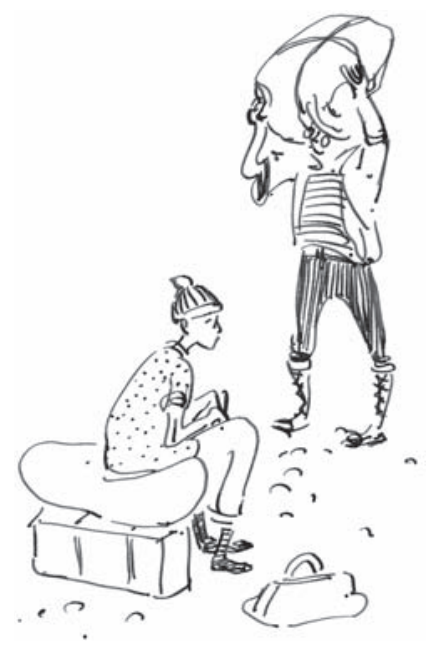


I call to remembrance my song in the night;

I commune with mine own heart; and my spirit made diligent search.

Psalm 77:6 


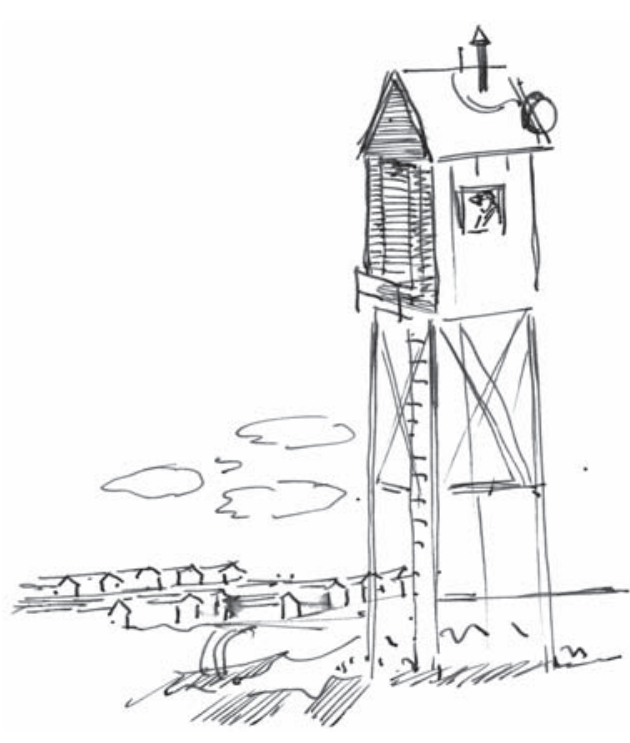

